\title{
Extending an indicator: year-round information on seabird trophic ecology from multiple-tissue stable-isotope analyses
}

\author{
Keith A. Hobson ${ }^{1, *}$, Alexander L. Bond ${ }^{1,2}$ \\ ${ }^{1}$ Environment Canada, 11 Innovation Blvd., Saskatoon, Saskatchewan S7N 3H5, Canada \\ ${ }^{2}$ Department of Biology, University of Saskatchewan, 112 Science Place, Saskatoon, Saskatchewan S7N 5E2, Canada
}

\begin{abstract}
Stable isotope analysis of tissues of seabirds and their prey has proven to be an extremely useful tool in seabird dietary studies in general and in the potential use of seabirds as ecological indicators in particular. The measurement of stable carbon $\left(\delta^{13} \mathrm{C}\right)$ and nitrogen $\left(\delta^{15} \mathrm{~N}\right)$ isotope values is important since they provide information on source of feeding and trophic position, respectively. However, the stable isotope approach provides information on spatial and trophic ecology of seabirds during a window of temporal integration that depends on the elemental turnover rate in the tissue being measured. Most researchers have relied on only 1 or 2 tissue types to study seabird diets and foraging ecology. Here, the potential for modeling trophic position and habitat use by seabirds over the annual cycle is demonstrated by using multiple tissues from the same individual. Isotopic measurements of bone collagen provide information integrated over the lifetime of the individual and those of feathers during the post-breeding molt period. Analysis of liver provides information integrated over the previous week and that of muscle integrated over a few months. We developed multi-tissue trophic models for thick-billed murre Uria lomvia, dovekie Alle alle, black guillemot Cepphus grylle, glaucous gull Larus hyperboreus, northern fulmar Fulmarus glacialis, black-legged kittiwake Rissa tridactyla, and ivory gull Pagophila eburnea using the Northwater Polynya in Northern Baffin Bay, 1998 to 1999. The careful application of stable isotope methods to a spectrum of tissue types represents a powerful means of extending our ability to investigate diet and potentially to use seabirds as ecological indicators.
\end{abstract}

KEY WORDS: Stable isotopes · Carbon-13 $\cdot$ Nitrogen-15 $\cdot$ Seabirds $\cdot$ Temporal integration

\section{INTRODUCTION}

The study of seabird feeding ecology in temperate and polar regions can reveal a great deal of information about the relative abundance and dynamics of marine prey, from herbivorous invertebrates to piscivorous fish and squid (Cairns 1987, Furness \& Camphuysen 1997, Barrett 2002, Piatt et al. 2007a). As such, a great deal of interest has emerged over the last few decades in using seabirds as indicators of the health of marine ecosystems (Diamond \& Devlin 2003, Burger \& Gochfeld 2004, Frederiksen et al. 2007, Montevecchi 2007, Piatt et al. 2007a, Durant et al. 2009), as well as the prevalence and biomagnification of contaminants (Jarman et al. 1996, Fisk et al. 2001, Braune et al. 2002). However, despite compelling reasons to investigate seabird diets, researchers face extraordinary challenges in obtaining even simple baseline data, especially outside the breeding season when birds are much less accessible. 
Stable isotope methods have been developed to study seabird trophic interactions (Hobson 1987, Hobson \& Welch 1992a, Hobson et al. 1994), and their application to consumers in the marine environment is now widely established. The essential advantage of the technique is that dietary or trophic information can be inferred based on the single isotopic measurement of an individual's tissue. When combined with conventional dietary techniques such as direct observation and stomach sampling and, more recently, with the measurement of fatty acids, the isotope technique can be a powerful and effective tool (Gilmour et al. 1995, Smith et al. 1996, Hooker et al. 2001, Dahl et al. 2003, Barrett et al. 2007, Karnovsky et al. 2012). Importantly, because different tissues reflect dietary integrations over different time periods, the sampling of several tissue types from the same individual can provide a time series analysis of dietary change. Hobson (1993) demonstrated this approach by modeling seabird trophic level based on bone collagen, muscle, and liver samples from 5 species of seabirds breeding in the Canadian high Arctic and so established long-term (i.e. years), intermediate (months), and short-term (days) dietary information, respectively. Many researchers have combined the analysis of non-destructive samples (e.g. feathers, red blood cells, blood plasma, claws), which only reflect short-term (days to weeks) foraging patterns (Hobson \& Clark 1992a,b). Few researchers have combined the analysis of several tissue types with varying integration periods from individual seabirds in order to reconstruct foraging patterns over at least an annual cycle.

In this paper, the power of isotopic analysis of multiple tissue types to infer seasonal dynamics of trophic level and source of feeding (i.e. use of productive inshore versus less productive offshore food webs and geographically diverse marine systems) is emphasized by providing the example of a multipletissue stable isotope analysis of 7 diverse species of seabirds using the Northwater Polynya between northern Canada and Greenland. The Northwater is the largest and most productive Arctic polynya, or seasonally ice-free body of water (Hobson et al. 2002). Each year, millions of seabirds migrate to the polynya to feed in its waters and to breed along its shores. Isotopic measurements of bone collagen provide information integrated over the previous months to years (Hobson \& Clark 1992a) and those of feathers during the post-breeding molt period. Analysis of liver tissue provides information integrated over the previous week and that of muscle for a few months depending on body mass (Hobson \& Clark 1992a).
Dovekies Alle alle breed in large numbers along the western coast of Greenland adjacent to the Northwater. These small subsurface feeders dive up to $35 \mathrm{~m}$ (Falk et al. 2000) and molt all of their primary flight feathers (hereafter 'primaries') after breeding (Stempniewicz 2001). Black guillemots Cepphus grylle are intermediate-sized diving alcids that feed on ice-associated invertebrates early in the breeding season and on benthic fish during breeding (Bradstreet \& Brown 1985, Byers et al. 2010), and replace their primaries following breeding (Ewins 1988). Thick-billed murres Uria lomvia are large subsurface divers that regularly reach depths over 70 m (Falk et al. 2002), and like dovekies, they replace all primaries at once following breeding in November/December (Huettmann \& Diamond 2000). Black-legged kittiwakes Rissa tridactyla and northern fulmars Fulmarus glacialis are surface feeders that also make shallow dives (Burtt 1974, Hobson \& Welch 1992b, Garthe \& Furness 2001). Fulmars replace primaries in July/August following breeding (Huettmann \& Diamond 2000, Allard et al. 2008), and kittiwakes molt their outer primaries after the breeding season in August/September (Meissner 2002). Ivory gulls Pagophila eburnea are listed as endangered in Canada, are declining (Gilchrist \& Mallory 2005), and are of interest due to their broad diet of fish and invertebrates and seasonal habit of scavenging marine mammal carcasses (Renaud \& McLaren 1982). Ivory gulls' outer primaries are replaced in August/September (Howell 2001). Glaucous gulls Larus hyperboreus are high trophic-level feeders during the breeding season, when they may consume eggs and young of other seabirds (Gilchrist et al. 1998). They replace their outermost primaries after breeding (Ingolfsson 1970). These 7 species represent the vast majority of seabirds utilizing the food web in the Northwater Polynya and encompass a broad diversity of feeding guilds.

The objectives of this study were to (1) demonstrate the utility of a multiple-tissue isotope approach to seabird dietary studies by constructing timeintegrated models of $\delta^{15} \mathrm{~N}$ and $\delta^{13} \mathrm{C}$ values in tissues of seabirds foraging in the Northwater Polynya, and (2) investigate annual community foraging dynamics in the Arctic. This was part of a larger study designed to investigate the importance of the polynya to seabirds and marine mammals and to investigate the role of seabirds in the flux and trophodynamics of nutrients and contaminants and their potential as ecological indicators (Hobson et al. 2002, Karnovsky \& Hunt 2002). 


\section{MATERIALS AND METHODS}

\section{Field collections}

As part of a larger study (Hobson et al. 2002), seabirds were collected (under a permit from the Canadian Wildlife Service) at sea throughout the Northwater Polynya by shooting. Birds were sexed by dissection after tissue sampling. Bird collections were made from a zodiac deployed from the CCGS 'Pierre Radisson' in May to July 1998 and August to September 1999. Due to the timing of research cruises, more than a full year passed between summer and fall collections.

\section{Stable isotope analysis}

Immediately after collection, small subsamples $(\sim 1 \mathrm{~g})$ of muscle and liver and 3 to $5 \mathrm{~g}$ of bone (humerus) and the outer 8th or 9th primary feather were collected from birds and frozen. Methods followed those described by Hobson et al. (2002). In the laboratory, muscle and liver tissue samples were thawed, washed in distilled water, freeze dried, powdered, and treated with a 2:1 chloroform:methanol solution to remove lipids (Bligh \& Dyer 1959, Kojadinovic et al. 2008b). Samples were then dried under a fume hood. Feathers were cleaned of surface oils using a 2:1 chloroform:methanol solution (Kojadinovic et al. 2008b) and dried under a fume hood, and then a small piece of the distal portion of the vane was used for isotope analysis. Bone samples with marrow removed were similarly cleaned in the solvent solution and dried. This material was then ground to a fine powder, and collagen was extracted according to procedures described by Hobson \& Montevecchi (1991).

Stable carbon and nitrogen isotope assays were performed on $1 \mathrm{mg}$ subsamples of homogenized materials by loading into tin cups and combusting at $1200^{\circ} \mathrm{C}$ in a Robo-Prep elemental analyzer. Resultant $\mathrm{CO}_{2}$ and $\mathrm{N}_{2}$ gases were then analyzed using an interfaced Europa 20:20 continuous-flow isotope ratio mass spectrometer, with every 5 unknowns separated by 2 laboratory standards. Stable isotope abundances were expressed in $\delta$ notation as the deviation from standards in parts per thousand (\%) according to the following equation:

$$
\delta X=\left\{\left(\mathrm{R}_{\text {sample }} / \mathrm{R}_{\text {standard }}\right)-1\right\}
$$

where $X$ is ${ }^{13} \mathrm{C}$ or ${ }^{15} \mathrm{~N}$ and $\mathrm{R}$ is the corresponding ratio ${ }^{13} \mathrm{C} /{ }^{12} \mathrm{C}$ or ${ }^{15} \mathrm{~N} /{ }^{14} \mathrm{~N}$. Isotopic reference materials were
Vienna Peedee Belemnite for $\delta^{13} \mathrm{C}$ and atmospheric $\mathrm{N}_{2}$ for $\delta^{15} \mathrm{~N}$ measurements. Replicate measurements of biologically relevant internal laboratory standards (albumen and whale baleen) indicated measurement errors of $\pm 0.1 \%$ and $\pm 0.3 \%$ for $\delta^{13} \mathrm{C}$ and $\delta^{15} \mathrm{~N}$ measurements, respectively.

\section{Trophic models and correcting for isotopic discrimination}

Consumer $\delta^{15} \mathrm{~N}$ depends not only on trophic position, but also on tissue- and species-specific discrimination factors (Caut et al. 2009). To compare trophic level (TL) based on isotopic measurement of different tissues, we used the following tissue-specific equation as described by Hobson et al. (1994):

$$
\mathrm{TL}_{\mathrm{X}}=3+\left(\delta^{15} \mathrm{~N}_{\mathrm{tx}}-\Delta \mathrm{d}_{\mathrm{tx}}-\delta^{15} \mathrm{~N}_{\mathrm{C}}\right) / 3.8
$$

where $\delta^{15} \mathrm{~N}_{\mathrm{tx}}$ is the stable nitrogen isotope ratio of bird tissue $x$ and $\delta^{15} \mathrm{~N}_{C}$ is the average value for Calanus hyperboreus, a dominant herbivorous copepod in the Northwater with an assumed TL of 2.0. We used an average value of $+7.9 \%$ for the $\delta^{15} \mathrm{~N}$ value for $C$. hyperboreus collected at the same time as our samples (Hobson et al. 2002). We used the following diet-tissue discrimination factors for $\mathrm{d}_{\mathrm{tx}}$ based on Mizutani et al. (1991, 1992): muscle $(+2.4 \%$ o), liver $(+2.3 \%)$, feather $(+4.4 \%)$, and bone collagen $(+3.9 \%$ o). We assumed the average trophic enrichment factor for Arctic food webs to be $+3.8 \%$ o (Hobson \& Welch 1992a).

Since isotopic discrimination values between diet and various tissues in animals vary by tissue type, in order to compare seabird $\delta^{13} \mathrm{C}$ values for different tissues, we first applied discrimination values to seabird tissue $\delta^{13} \mathrm{C}$ values in order to derive expected prey $\delta^{13} \mathrm{C}$ values. Again, based on Mizutani et al. $(1991,1992)$, we subtracted the following discrimination values from tissue values: muscle $(+2.1 \%$ ), liver $(+1.3 \%)$, feather $(+3.3 \%$ ), and bone collagen $(+2.5 \%)$. Data from seabird muscle were presented by Hobson et al. (2002), and data from ivory gull tissues by Karnovsky et al. (2009).

\section{Statistical analysis}

We analyzed TL and $\delta^{13} \mathrm{C}$ by period (tissue) and sex using a multivariate analysis of variance (MANOVA) for each species in SPSS 19 (IBM). When MANOVA results were significant as determined by Wilks' $\lambda$, we used univariate ANOVAs with Ryan's $Q$ post hoc 
test to examine differences among periods (Ryan 1959, 1960, Day \& Quinn 1989). Ryan's Q gives $p$ values $\left(\mathrm{p}_{Q}\right)$ of group similarity, where identical members of a group have $p=1.0$, so we report $1-p_{Q}$. Because prey-tissue discrimination factors are species-specific (Caut et al. 2009), and are not known for any of the seabirds examined here (Bond \& Jones 2009), we did not test for differences in prey $\delta^{13} \mathrm{C}$ or TL among species.

\section{RESULTS}

All species differed in TL and/or prey $\delta^{13} \mathrm{C}$ by period (Wilks' $\lambda$, all $\mathrm{p}<0.001$ ); black guillemots, northern fulmars, and glaucous gulls differed by sex; the sex $\times$ period interaction was significant only in black guillemots (Table 1, Figs. 1 \& 2). Stable isotope values $\left(\delta^{15} \mathrm{~N}, \delta^{13} \mathrm{C}\right)$ for the 7 seabird species are presented in Appendix 1.

\section{Dovekie}

For the dovekie, there were no effects of sex on either prey $\delta^{13} \mathrm{C}$ or TL (Wilks' $\lambda=0.988, \mathrm{p}=0.29$ ), and the sex $\times$ period interaction was not significant (Wilks' $\lambda=0.996, \mathrm{p}=0.99$ ). TL differed by period $\left(F_{3,212}=91.21, \mathrm{p}<0.001\right)$, was highest in winter (Ryan's $Q, \mathrm{p}<0.001)$, lowest in summer ( $<<0.001)$, and intermediate during breeding and annually $(\mathrm{p}=$ $0.84)$. Prey $\delta^{13} \mathrm{C}$ differed by period $\left(F_{3,212}=8.51, \mathrm{p}<\right.$ 0.001 ), was highest in annual measurements ( $\mathrm{p}<$ $0.001)$, but did not differ among summer, breeding, and winter $(\mathrm{p}=0.94)$.

\section{Black guillemot}

For the black guillemot, sex (Wilks' $\lambda=0.812, \mathrm{p}=$ 0.005 ), period (Wilks' $\lambda=0.304, p<0.001$ ), and the sex $\times$ period interaction (Wilks' $\lambda=0.655, \mathrm{p}=0.001$ ) were significant overall. TL differed by period $\left(F_{1,51}=\right.$ $14.685, \mathrm{p}<0.001)$, but not by $\operatorname{sex}\left(F_{1,51}=0.968, \mathrm{p}=\right.$ 0.33 ), and the sex $\times$ period interaction was not significant $\left(F_{3,51}=0.071, \mathrm{p}=0.11\right)$. TL was highest during breeding $(\mathrm{p}<0.001)$, and lower during the summer, winter, and annually $(\mathrm{p}=0.94)$. Prey $\delta^{13} \mathrm{C}$ was different between sexes $\left(F_{1,51}=6.541, \mathrm{p}=0.014\right)$ and among periods $\left(F_{1,51}=8.880, \mathrm{p}<0.001\right)$, and the sex $\times$ period interaction was significant $\left(F_{3,51}=5.129, \mathrm{p}=\right.$ 0.004 ), so we examined differences within each sex using ANOVA. There was no significant difference in

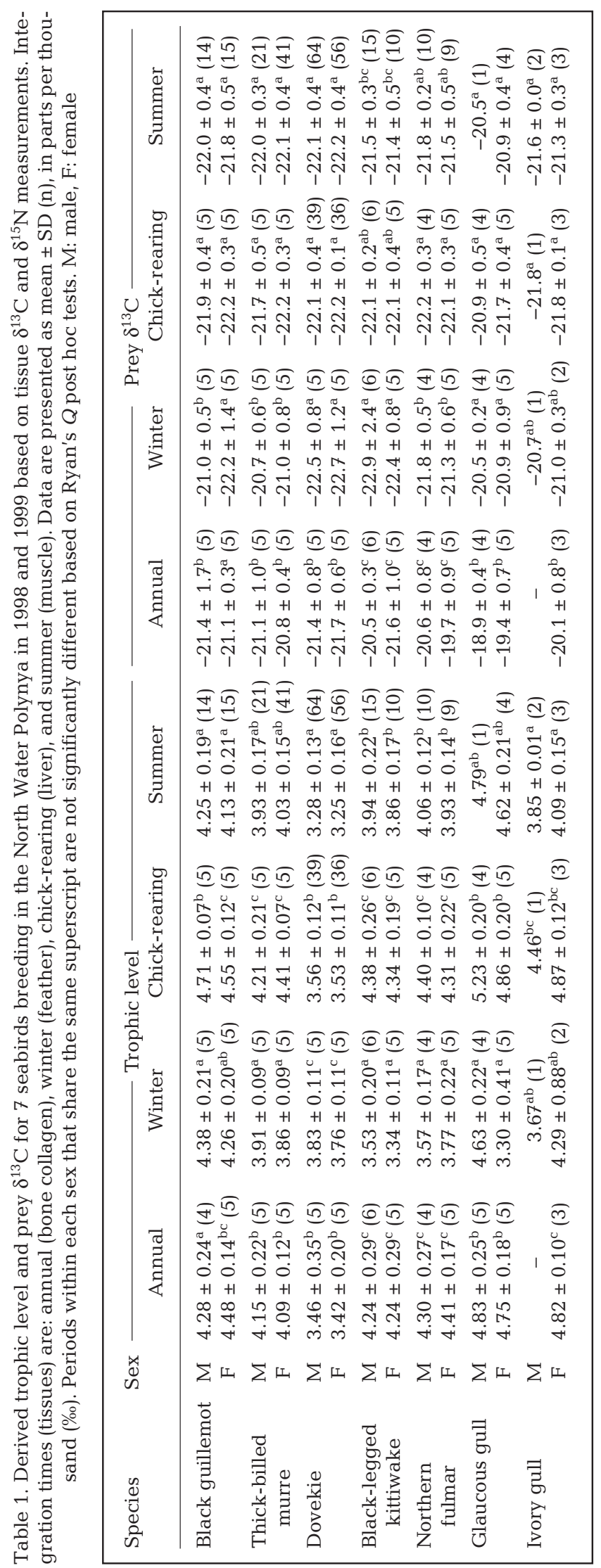



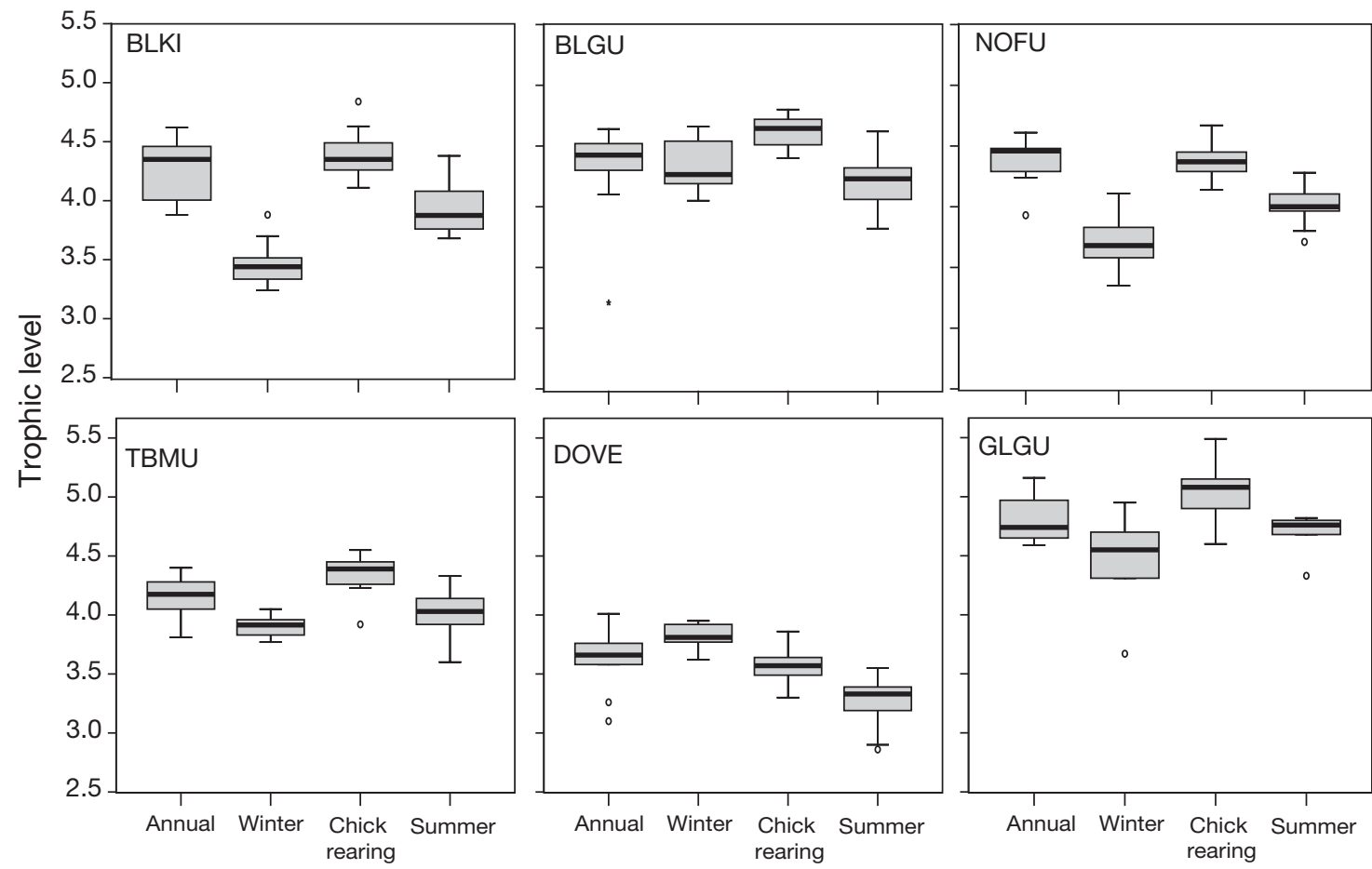

Period

Fig. 1. Changes in derived trophic level by period for seabirds using the Northwater Polynya in 1998 and 1999. Annual data are based on bone collagen, winter data on primary feathers, chick-rearing data on liver, and summer data on muscle tissue. Blacklegged kittiwake (BLKI), black guillemot (BLGU), northern fulmar (NOFU), thick-billed murre (TBMU), dovekie (DOVE), and glaucous gull (GLGU). Box plots: solid black line indicates the mean, boxes 25 and $75 \%$, whiskers 10 and $90 \%$, and dots are outliers
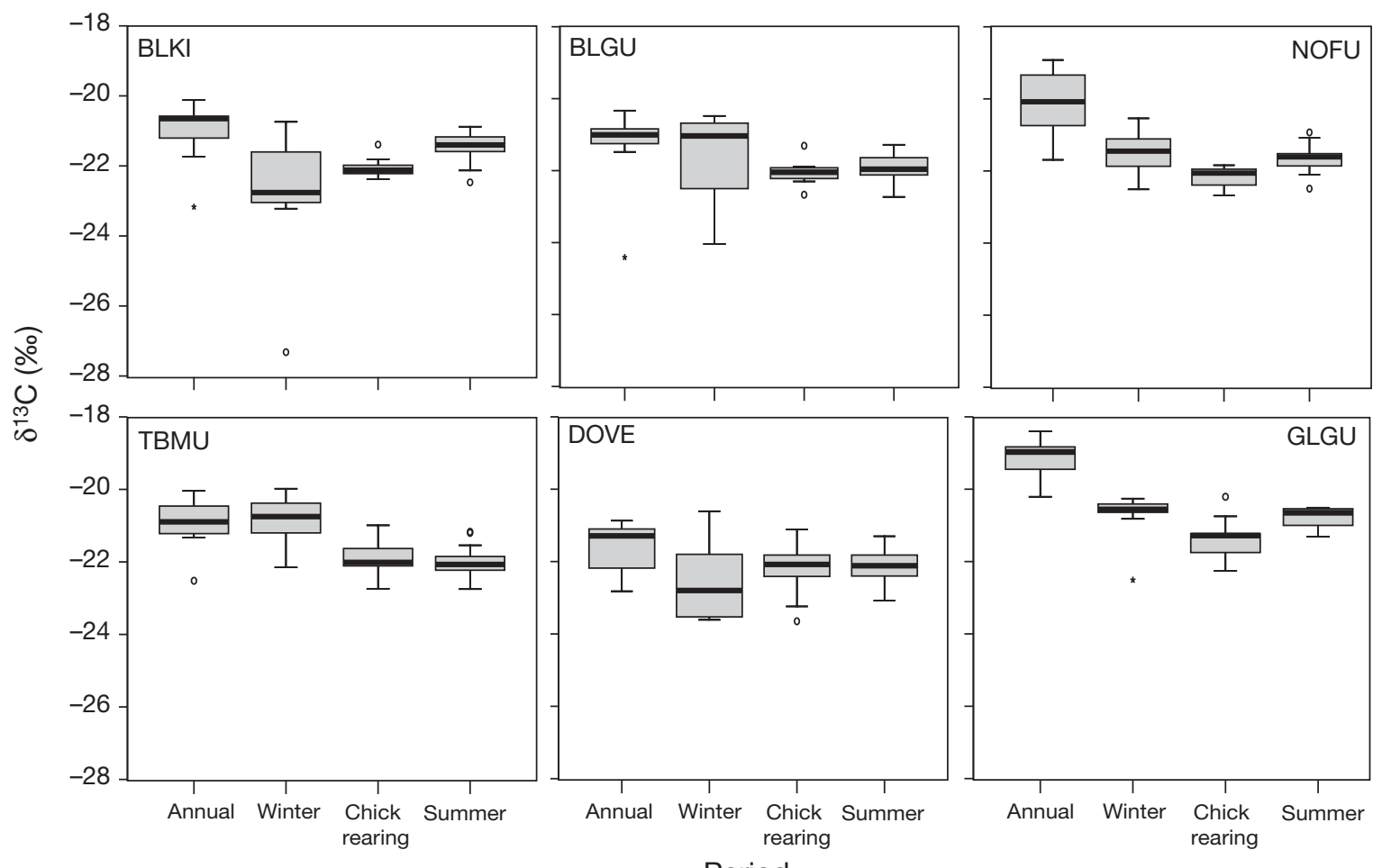

Fig. 2. Changes in derived seabird prey $\delta^{13} \mathrm{C}$ values by period for seabirds using the Northwater Polynya in 1998 and 1999. Annual data are based on bone collagen, winter data on primary feathers, chick-rearing data on liver, and summer data on muscle tissue. Species codes and other details as in Fig. 1 
prey $\delta^{13} \mathrm{C}$ among periods in females $(\mathrm{p}=0.91)$, but males' prey $\delta^{13} \mathrm{C}$ was lowest in the summer and during breeding $(\mathrm{p}=0.18)$, and highest during winter and annually $(\mathrm{p}=0.39)$. Males' TL was highest during breeding $(p<0.001)$ and did not differ among other periods $(p=0.49)$. In females, the lowest TL was observed during summer and winter $(p=0.52)$, with the highest overall and during breeding $(p=0.18)$. Winter and annual TL were also statistically similar $(p=0.83)$.

\section{Thick-billed murre}

For the thick-billed murre, sex (Wilks' $\lambda=0.977, \mathrm{p}=$ 0.38 ), and the sex $\times$ period interaction (Wilks' $\lambda=$ $0.889, \mathrm{p}=0.13$ ) were not significant, but there were overall differences among periods (Wilks' $\lambda=0.26$, $\mathrm{p}<0.001)$. TL differed among periods $\left(F_{3,84}=17.60\right.$, $\mathrm{p}<0.001)$, with the highest TL during breeding $(\mathrm{p}<$ $0.001)$, and the lowest during winter and summer ( $p=$ $0.81)$; annual TL did not differ from summer TL $(\mathrm{p}=$ $0.87)$. Prey $\delta^{13} \mathrm{C}$ also differed among period $\left(F_{3,84}=\right.$ $33.80, \mathrm{p}<0.001)$ with summer and breeding $\delta^{13} \mathrm{C}$ forming 1 homogenous subset $(p=0.20)$, and annual and winter forming another higher subset $(p=0.15)$.

\section{Northern fulmar}

For the northern fulmar, there were overall differences by sex (Wilks' $\lambda=0.84, p=0.041$ ) and period (Wilks' $\lambda=0.10, p<0.001$ ), but the sex $\times$ period interaction was not significant (Wilks' $\lambda=0.79, \mathrm{p}=0.17$ ). There was no difference between sexes in TL $\left(F_{1,38}=\right.$ $0.13, p=0.72$ ), but prey $\delta^{13} \mathrm{C}$ was significantly lower in females than males in all seasons $\left(F_{1,38}=7.16, \mathrm{p}=\right.$ $0.011)$. TL was highest in breeding and annually $(\mathrm{p}<$ $0.02)$, lowest in winter $(p<0.001)$, and intermediate in summer $(p<0.001)$. Prey $\delta^{13} \mathrm{C}$ was highest annually ( $p<0.001)$, lowest during breeding and summer $(p=0.90)$, and intermediate during winter and summer $(p=027)$.

\section{Black-legged kittiwake}

For the black-legged kittiwake, there was no effect of sex (Wilks' $\lambda=0.97, p=0.48$ ), and the sex $\times$ period interaction was not significant (Wilks' $\lambda=0.87, \mathrm{p}=$ 0.31 ); period did have an overall effect (Wilks' $\lambda=$ $0.22, \mathrm{p}<0.001)$. TL differed among periods $\left(F_{3,51}=\right.$ $40.12, \mathrm{p}<0.001)$, with the lowest TL during winter $(p<0.001)$ and the highest during breeding/annual $(p=0.62)$. Summer TL was intermediate, but significantly different from other periods $(\mathrm{p}<0.001)$. Prey $\delta^{13} \mathrm{C}$ also differed among periods $\left(F_{3,51}=8.10, \mathrm{p}<\right.$ 0.001 ), with the lowest $\delta^{13} \mathrm{C}$ during winter and breeding $(p=0.80)$, and the highest during summer and annually ( $p=0.58)$; summer and breeding $\delta^{13} \mathrm{C}$ were also similar $(p=0.83)$.

\section{Ivory gull}

For the ivory gull, period (Wilks' $\lambda=0.05, \mathrm{p}=$ 0.001 ), but neither sex (Wilks' $\lambda=0.64, p=0.20$ ) nor the sex $\times$ period interaction (Wilks' $\lambda=0.63, p=0.72$ ), influenced foraging overall. TL differed among period $\left(F_{3,8}=6.27, \mathrm{p}=0.017\right)$ : the lowest TL was during summer and winter $(p=0.07)$, the highest during breeding and annually $(\mathrm{p}=0.06)$, while winter and breeding TL were not significantly different $(\mathrm{p}=$ $0.94)$. Prey $\delta^{13} \mathrm{C}$ also differed by period $\left(F_{3,8}=11.85\right.$, $\mathrm{p}=0.003)$, with the lowest prey $\delta^{13} \mathrm{C}$ during breeding, summer, and winter $(p=0.92)$, and the highest during winter and annually $(\mathrm{p}=0.93)$.

\section{Glaucous gull}

Sex (Wilks' $\lambda=0.77, p=0.047$ ) and period (Wilks' $\lambda=0.12, \mathrm{p}<0.001$ ), but not their interaction (Wilks' $\lambda=0.91, \mathrm{p}=0.88$ ), were significant overall for the glaucous gull. TL $\left(F_{1,24}=5.47, \mathrm{p}=0.028\right)$ and prey $\delta^{13} \mathrm{C}\left(F_{1,24}=4.61, \mathrm{p}=0.042\right)$ were significantly higher in males. TL differed by period $\left(F_{3,24}=7.77, \mathrm{p}=\right.$ 0.001), with the highest TL during breeding, and annually ( $p=0.93$ ), and the lowest TL during winter $(p=0.62)$ and intermediate in summer. Prey $\delta^{13} \mathrm{C}$ also differed among periods $\left(F_{3,24}=21.47, \mathrm{p}<0.001\right)$, with high $\delta^{13} \mathrm{C}$ over the year $(\mathrm{p}<0.001)$ and lower $\delta^{13} \mathrm{C}$ during all other periods $(p=0.90)$.

\section{DISCUSSION}

This study has demonstrated that the isotopic composition of seabird tissues that reflect diet and trophic position are dynamic, and so determination of these factors for 1 period of the annual cycle cannot necessarily be extrapolated to other periods. However, by examining multiple tissues isotopically, it is possible to infer diet and trophic position approximating the major phases of the annual cycle of individuals. Winter diet in particular consisted of lower TL prey for black-legged kittiwake, northern fulmar, glaucous 
gull, thick-billed murre, and male black guillemots compared with other periods. For murres, this trend was recently confirmed through the isotopic measurement of muscle tissue of wintering birds off Newfoundland (Moody \& Hobson 2007) where euphausiids contributed substantially to diet. For surface-feeding seabirds like kittiwakes and fulmars, it is possible that invertebrate prey were more available during the molting period at sea. Black guillemots, which are year-round residents of Arctic waters, showed the most consistent TL throughout the year, and this species likely makes use of ice-associated invertebrates primarily during spring and benthic fish at other times. As expected, dovekies showed the lowest TL of all species examined, but there was evidence that trophic position was lowest during the summer. Stomach content analyses of dovekies using the Northwater Polynya confirm that herbivorous copepods dominate the diet early in the year. More carnivorous copepods, the amphipod Themisto libellula, small Arctic cod Boreogadus saida, and other invertebrates tend to dominate in late summer and autumn (Karnovsky et al. 2008), but lower-trophic prey likely comprise the majority of dovekies' winter diet (Fort et al. 2010). Glaucous gulls showed the highest TL of all species, and this was fairly constant with the possible exception of the winter molt period.

In contrast to TL estimates, derived prey $\delta^{13} \mathrm{C}$ values did not vary greatly among species or within species annually. Although glaucous gulls had among the highest values among tissues, the range of $\delta^{13} \mathrm{C}$ values within tissues was typically in the order of 1 to $2 \%$. Stable carbon isotope ratios can be influenced by a variety of processes in marine systems (Michener \& Schell 1994), but it is generally assumed that food webs involving carbon derived from benthos are more enriched in ${ }^{13} \mathrm{C}$ than pelagic food webs. Indeed, in the nearby Lancaster Sound food web, Hobson \& Welch (1992a) determined that muscle of black guillemots had among the highest $\delta^{13} \mathrm{C}$ value, whereas muscle $\delta^{13} \mathrm{C}$ values from dovekies and fulmars were among the lowest. That we did not find a similar pattern among the seabirds of the Northwater Polynya, where all 3 species' prey had low $\delta^{13} \mathrm{C}$, suggests that seabird diets there were dominated primarily by a pelagic food web. Furthermore, estimated prey $\delta^{13} \mathrm{C}$ among species during the summer and breeding seasons, when birds are present in the Northwater, varied little (Table 1). Nonetheless, in general, $\delta^{13} \mathrm{C}$ measurements of seabird tissues are encouraged since patterns of this isotope can vary spatially (Schell et al. 1998, Rau et al. 2001) and can provide useful information on source or latitude of feeding in some areas (Hobson et al. 1994, Cherel et al. 2006, Jaeger et al. 2010).

We found no difference between sexes in TL, and $\delta^{13} \mathrm{C}$ differed between sexes in only 3 cases (black guillemot, northern fulmar, and glaucous gull). Male fulmars' $\delta^{13} \mathrm{C}$ was lower relative to that of females, and this pattern was reversed in glaucous gulls. In black guillemots, males had lower $\delta^{13} \mathrm{C}$ prey relative to females, except during the summer when this trend was reversed. In some species, differences in foraging between sexes can have demographic and behavioral consequences (Awkerman et al. 2007). Given the pelagic-dominated Northwater system, the relatively small difference in absolute terms (generally $<2 \%$ ), and the fact that males and females were not from the same pair, sex differences in the prey $\delta^{13} \mathrm{C}$ during the breeding season in these species require further attention. Outside the breeding season, sex and individual differences in $\delta^{13} \mathrm{C}$ could point to spatial or trophic segregation.

Large amounts of variation around isotopic population means could be the result of specialization at the group or individual level, whereas low variance within species would also indicate specialization. Even within sexes, the variation around TL and prey $\delta^{13} \mathrm{C}$ values suggests some degree of individual differences (e.g. female black guillemots, or male blacklegged kittiwakes in winter) in migration strategies (Quillfeldt et al. 2010).

The analysis of tissues with varying rates of turnover (and therefore differing in the length of time over which foraging is integrated) can provide insight into species' ecology that would otherwise be expensive, laborious, or even impossible to determine. In the Northwater Polynya, all of the seabirds we examined showed a higher trophic position during chick-rearing (liver) than during the breeding season as a whole. This could be the result of prey switching, within-season increases in prey $\delta^{15} \mathrm{~N}$, or both. Other seabirds have also shown this increase in $\delta^{15} \mathrm{~N}$ during chick rearing (e.g. Davies et al. 2009). At the same time, there were no significant differences in prey $\delta^{13} \mathrm{C}$ between the chick-rearing and integrated summer diet (Table 1).

There is a long history of using seabird communities to study inter-specific foraging patterns and resource partitioning using stable isotopes (e.g. Hobson et al. 1994, Forero et al. 2004, Kojadinovic et al. 2008a), and some studies have used multiple tissues with rapid turnover (blood, feathers) to assess interseasonal differences (e.g. Davies et al. 2009, Fort et al. 2010, Young et al. 2010). The advantage of our multiple-tissue approach is that the integration pe- 
riod for which foraging is assessed is extended by using tissues with slow metabolic turnover like muscle and bone collagen. Collagen is a tissue that has seldom been used in avian isotopic studies (Hobson 1990, Hobson et al. 1994, Steele 2005), but it can provide information on individuals' lifetime average diet (Schoeninger \& DeNiro 1984). Because inter-annual variation is dampened by the integrative and slow nature of bone collagen protein turnover, analysis of collagen for isotope values can be a powerful tool for examining long-term ecosystem changes using seabirds as indicators.

Previously, seabird dietary analyses were necessarily based on the frequency of occurrence of prey items in stomachs, deliveries to chicks, pellets, or other dietary remains (Duffy \& Jackson 1986, Barrett et al. 2007). While these data provide valuable taxonomic information on diets, they are limited from an analytical perspective. An advantage to deriving seabird TL based on seabird $\delta^{15} \mathrm{~N}$ and $\delta^{13} \mathrm{C}$ values is that these are continuous variables that each summarize different aspects of foraging in a single number, and thus are amenable to more extensive mathematical analysis (Karnovsky et al. 2012).

One area of particular interest is using stable isotope data to examine the bioaccumulation and acquisition of contaminants in food webs. For example, biomagnification of contaminants can be quantified as the slope of the relationship between contaminant concentration (typically on a logarithmic scale) and tissue $\delta^{15} \mathrm{~N}$ value or derived TL (Jarman et al. 1996, Braune et al. 2001, Fisk et al. 2001). Changes in contaminant levels over time can also be adjusted to account for dietary shifts using stable isotope values (Braune 2007). Previous studies have typically used a single consumer tissue type for quantifying such contaminant-TL level relationships, but, as demonstrated here, several tissue types could provide information for various time periods during the annual cycle. Such analyses could identify the location where contaminants are accumulated, even if the sites are beyond the immediate place of collection (Ofukany et al. 2012). In a more indirect way, derivation of periods or locations where TL is highest using tissuedependent isotopic modeling allows the identification of those components of the annual cycle where species are most vulnerable to contaminant accumulation. We caution, however, that the integration periods of contaminants and stable isotopes must be comparable for a meaningful analysis (Bond 2010).

In many situations, actual collections of seabirds are necessary to obtain the appropriate tissues for multi-tissue isotopic sampling. This is typically the case with at-sea work. However, at colony sites, adults and chicks can usually be captured, providing the opportunity for non-destructive sampling. Whole blood has a similar turnover rate to avian muscle (Hobson \& Clark 1992a), as do plasma and liver (Hobson \& Clark 1993). Due to similar elemental turnover rates, blood separated into plasma and cellular fractions provides equivalent isotopic information as liver and muscle, respectively (Hobson \& Clark 1993). The isotopic analysis of claws may also provide information on TL and source of feeding over a period of several months of growth (Bearhop et al. 2003). Indeed, the only tissue that appears to be impossible to replace non-destructively is bone collagen, which provides a convenient means of assaying lifetime (or at least annual) average integrations of diet and stable isotope values. Some seabirds have a protracted period of sequential feather growth, and by sampling and isotopically measuring the vanes of several feathers from an individual, it may be possible to extend the period of inference to several months or years (Pyle 2009, Ofukany et al. 2012).

The isotope approach is well suited to deriving estimates of trophic position and source of feeding for those tissues associated with food webs that have been well described. This was the case for seabird muscle and liver tissues sampled in the Northwater Polynya since those tissues were synthesized there and we had an extensive isotopic survey of the polynya food web. However, inferences based on those tissues grown outside of the polynya, possibly including feathers and components of the bone collagen, may be less reliable if the marine food web differed substantively from that of the polynya. This is currently a challenge for many applications of the isotope technique because patterns and dynamics of marine isoscapes are not well known (Karnovsky et al. 2012). Similarly, some marine food webs can change isotopically across seasons or years, and such factors can affect the reliability of trophic estimates. Nonetheless, there is some evidence for long-term stability in the isotopic nature of marine food webs involving seabirds in the vicinity of the polynya (Moody et al. 2012), and the integrative nature of isotopic averaging is expected to dampen isotopic variation that may occur at lower TLs (Hobson 2011).

There has been considerable discussion about when seabirds can be used as reliable ecological indicators (e.g. Piatt et al. 2007a,b, Durant et al. 2009). A general prerequisite for any indicator is that we know what it is indicating. Since diet links seabirds with their marine environment, the accurate determination of seabird diet or trophic position is an essential 
component of the indicator approach. This study has shown that by using several tissue types from the same individuals, stable isotope assays can be a more informative approach to defining seabird TL and general source of feeding. Future studies are now required to better refine and test the time-integrated models by establishing additional estimates of the diet-tissue discrimination factors upon which the models are based. In addition, studies that help define isotopic patterns in marine food webs (i.e. marine isoscapes) and the distribution of seabirds during the non-breeding season will ultimately benefit isotopic studies of seabirds as ecological indicators since it will allow greater inference on movements and the interpretation of corresponding tissue isotopic records (Minami \& Ogi 1997, Barnes et al. 2009, Graham et al. 2010, Jaeger et al. 2010, Block et al. 2011).

Acknowledgements. We thank the crew, officers, and captains of the CCGS 'Louis St. Laurent' and 'Pierre Radisson' for their enthusiastic assistance. Thanks to the Hunters Trappers Organizations of Grise Fiord, Nunavut, and Qaanaaq, Greenland, for permission for the project to collect birds in their regions. P. Akeeagok, D. Andriashek, W. Calvert, J. Carlson, A. Fisk, M. Holst, N. Karnovsky, N. Lunn, I. Stirling, and J. Zamon provided assistance in the field. Thanks to chief scientists L. Fortier, M. Gosselin, and B. Hargrave for their support throughout the project. P. Healy performed stable isotope sample preparation. Stable isotope measurements were conducted at the Department of Soil Science, University of Saskatchewan. A grant to K.A.H. and post-doctoral fellowship to A.L.B. from the Natural Sciences and Engineering Research Council of Canada and an operating grant to K.A.H. from the Canadian Wildlife Service supported this work. Comments from 3 anonymous reviewers improved this manuscript.

\section{LITERATURE CITED}

Allard KA, Mallory ML, Wilcox KL, Forbes MR (2008) Prebasic molt initiation and progress in northern fulmars of the High Arctic: Do molt and breeding overlap? Polar Biol 31: 181-188

> Awkerman JA, Hobson KA, Anderson DJ (2007) Isotopic $\left(\delta^{15} \mathrm{~N}\right.$ and $\left.\delta^{13} \mathrm{C}\right)$ evidence for intersexual foraging differences and temporal variation in habitat use in waved albatrosses. Can J Zool 85:273-279

Barnes C, Jennings S, Barry JT (2009) Environmental correlates of large-scale spatial variation in the $\delta^{13} \mathrm{C}$ of marine animals. Estuar Coast Shelf Sci 81:368-374

> Barrett RT (2002) Atlantic puffin Fratercula arctica and common guillemot Uria aalge chick diet and growth as indicators of fish stocks in the Barents Sea. Mar Ecol Prog Ser 230:275-287

> Barrett RT, Camphuysen K, Anker-Nilssen T, Chardine JW and others (2007) Diet studies of seabirds: a review and recommendations. ICES J Mar Sci 64:1675-1691

Bearhop S, Furness RW, Hilton GM, Votier SC, Waldron S (2003) A forensic approach to understanding diet and habitat use from stable isotope analysis of (avian) claw material. Funct Ecol 17:270-275
Bligh EG, Dyer WJ (1959) A rapid method of total lipid extraction and purification. Can J Biochem Physiol 37: 911-917

Block BA, Jonsen ID, Jorgensen SJ, Winship AJ and others (2011) Tracking apex marine predator movements in a dynamic ocean. Nature 475:86-90

> Bond AL (2010) Relationships between stable isotopes and metal contaminants in feathers are spurious and biologically uninformative. Environ Pollut 158:1182-1184

Bond AL, Jones IL (2009) A practical introduction to stableisotope analysis for seabird biologists: approaches, cautions and caveats. Mar Ornithol 37:183-188

Bradstreet MS, Brown RGB (1985) Feeding ecology of the Atlantic Alcidae. In: Nettleship DN, Birkhead TR (eds) The Atlantic Alcidae: the evolution, distribution and biology of the auks inhabiting the Atlantic Ocean and adjacent water areas. Academic Press, London, p 264-318

$>$ Braune BM (2007) Temporal trends of organochlorines and mercury in seabird eggs from the Canadian Arctic, 1975-2003. Environ Pollut 148:599-613

Braune BM, Donaldson GM, Hobson KA (2001) Contaminant residues in seabird eggs from the Canadian Arctic. Part I. Temporal trends 1975-1998. Environ Pollut 114: 39-54

> Braune BM, Donaldson GM, Hobson KA (2002) Contaminant residues in seabird eggs from the Canadian Arctic. II. Spatial trends and evidence from stable isotopes for intercolony differences. Environ Pollut 117:133-145

> Burger J, Gochfeld M (2004) Marine birds as sentinels of environmental pollution. EcoHealth 1:263-274

Burtt EH (1974) Success of two feeding methods of the Black-legged Kittiwake. Auk 91:827-829

> Byers T, Smith A, Mallory ML (2010) Diet of black guillemots and northern fulmars breeding beside a High Arctic polynya. Polar Biol 33:457-467

Cairns DK (1987) Seabirds as indicators of marine food supplies. Biol Oceanogr 5:261-271

Caut S, Angulo E, Courchamp F (2009) Variation in discrimination factors $\left(\Delta^{15} \mathrm{~N}\right.$ and $\left.\Delta^{13} \mathrm{C}\right)$ : the effect of diet isotopic values and applications for diet reconstruction. J Appl Ecol 46:443-453

> Cherel Y, Phillips RA, Hobson KA, McGill RAR (2006) Stable isotope evidence of diverse species-specific and individual wintering strategies in seabirds. Biol Lett 2:301-303

$>$ Dahl TM, Falk-Petersen S, Gabrielsen GW, Sargent JR, Hop H, Millar RM (2003) Lipids and stable isotopes in common eider, black-legged kittiwake and northern fulmar: a trophic study from an Arctic fjord. Mar Ecol Prog Ser 256:257-269

> Davies WE, Hipfner JM, Hobson KA, Ydenberg RC (2009) Seabird seasonal trophodynamics: isotopic patterns in a community of Pacific alcids. Mar Ecol Prog Ser 382: 211-219

> Day RW, Quinn GP (1989) Comparisons of treatments after an analysis of variance in ecology. Ecol Monogr 59: 433-463

> Diamond AW, Devlin CM (2003) Seabirds as indicators of changes in marine ecosystems: ecological monitoring on Machias Seal Island. Environ Monit Assess 88:153-175

> Duffy DC, Jackson S (1986) Diet studies of seabirds: a review of methods. Colon Waterbirds 9:1-17

Durant JM, Hjermann DØ, Frederiksen M, Charrassin JB and others (2009) Pros and cons of using seabirds as ecological indicators. Clim Res 39:115-129

$>$ Ewins PJ (1988) The timing of moult in Black Guillemots Cepphus grylle in Shetland. Ringing Migr 9:5-10

> Falk K, Egevang Pedersen C, Kampp K (2000) Measure- 
ments of diving depth in Dovekies (Alle alle). Auk 117: 522-525

Falk K, Benvenuti S, Dall'Antonia L, Gilchrist HG, Kampp K (2002) Foraging behaviour of thick-billed murres breeding in different sectors of the North Water polynya: an inter-colony comparison. Mar Ecol Prog Ser 231:293-302

> Fisk AT, Hobson KA, Norstrom RJ (2001) Influence of chemical and biological factors on trophic transfer of persistent organic pollutants in the Northwater Polynya marine food web. Environ Sci Technol 35:732-738

Forero MG, Bortolotti GR, Hobson KA, Donázar JA, Bertelloti M, Blanco G (2004) High trophic overlap within the seabird community of Argentinean Patagonia: a multiscale approach. J Anim Ecol 73:789-801

Fort J, Cherel Y, Harding AMA, Welcker J and others (2010) Geographic and seasonal variability in the isotopic niche of little auks. Mar Ecol Prog Ser 414:293-302

> Frederiksen M, Mavor RA, Wanless S (2007) Seabirds as environmental indicators: the advantages of combining data sets. Mar Ecol Prog Ser 352:205-211

Furness RW, Camphuysen K (1997) Seabirds as monitors of the marine environment. ICES J Mar Sci 54:726-737

$>$ Garthe S, Furness RW (2001) Frequent shallow diving by a Northern Fulmar feeding at Shetland. Waterbirds 24: 287-289

Gilchrist HG, Mallory ML (2005) Declines in abundance and distribution of the ivory gull (Pagophila eburnea) in Arctic Canada. Biol Conserv 121:303-309

Gilchrist HG, Gaston AJ, Smith JNM (1998) Wind and prey nest sites as foraging constraints on an avian predator, the glaucous gull. Ecology 79:2403-2414

> Gilmour I, Johnston MA, Pillinager CT, Pond CM, Mattacks CA, Prestrud P (1995) The carbon isotopic composition of individual fatty acids as indicators of dietary history in arctic foxes on Svalbard. Philos Trans R Soc Lond B Biol Sci 349:135-142

Graham BS, Koch PL, Newsome SD, McMahon KW, Aurioles D (2010) Using isoscapes to trace the movements and foraging behavior of top predators in oceanic ecosystems. In: West JB, Bowen GJ, Dawson TE, Tu KP (eds) Isoscapes: understanding movement, pattern, and process on Earth through isotope mapping. Springer, New York, NY, p 299-318

Hobson KA (1987) Use of stable-carbon isotope analysis to estimate marine and terrestrial protein content in gull diets. Can J Zool 65:1210-1213

> Hobson KA (1990) Stable isotope analysis of Marbled Murrelets: evidence for freshwater feeding and determination of trophic level. Condor 92:897-903

> Hobson KA (1993) Trophic relationships among high Arctic seabirds: insights from tissue-dependent stable-isotope models. Mar Ecol Prog Ser 95:7-18

Hobson KA (2011) Isotopic ornithology: a perspective. J Ornithol 152(Suppl 1):49-66

Hobson KA, Clark RG (1992a) Assessing avian diets using stable isotopes I: turnover of ${ }^{13} \mathrm{C}$ in tissues. Condor 94: 181-188

> Hobson KA, Clark RG (1992b) Assessing avian diets using stable isotopes II: factors affecting diet-tissue fractionation. Condor 94:189-197

Hobson KA, Clark RG (1993) Turnover of ${ }^{13} \mathrm{C}$ in cellular and plasma fractions of blood: implications for nondestructive sampling in avian dietary studies. Auk 110:638-641

- Hobson KA, Montevecchi WA (1991) Stable isotope determinations of trophic relationships of great auks. Oecologia 87:528-531

> Hobson KA, Welch HE (1992a) Determination of trophic relationships within a high Arctic marine food web using $\delta^{13} \mathrm{C}$ and $\delta^{15} \mathrm{~N}$ analysis. Mar Ecol Prog Ser 84:9-18

Hobson KA, Welch HE (1992b) Observations of foraging northern fulmars (Fulmarus glacialis) in the Canadian High Arctic. Arctic 45:150-153

Hobson KA, Piatt JF, Pitocchelli J (1994) Using stable isotopes to determine seabird trophic relationships. J Anim Ecol 63:786-798

$>$ Hobson KA, Fisk AT, Karnovsky NJ, Holst M, Gagnon JM, Fortier M (2002) A stable isotope $\left(\delta^{13} \mathrm{C}, \delta^{15} \mathrm{~N}\right)$ model for the North Water food web: implications for evaluating trophodynamics and the flow of energy and contaminants. Deep-Sea Res II 49:5131-5150

- Hooker SK, Iverson SJ, Ostrom PH, Smith SC (2001) Diet of northern bottlenose whales inferred from fatty-acid and stable-isotope analyses of biopsy samples. Can J Zool 79: 1442-1454

> Howell SNG (2001) Molt of the Ivory Gull. Waterbirds 24: 438-442

> Huettmann F, Diamond AW (2000) Seabird migration in the Canadian northwest Atlantic Ocean: moulting locations and movement patterns of immature birds. Can J Zool 78:624-647

Ingolfsson A (1970) The moult of remiges and retrices in Great Black-backed Gulls Larus marinus and Glaucous Gulls L. hyperboreus in Iceland. Ibis 112:83-92

> Jaeger A, Lecomte VJ, Weimerskirch H, Richard P, Cherel Y (2010) Seabird satellite tracking validates the use of latitudinal isoscapes to depict predators' foraging areas in the Southern Ocean. Rapid Commun Mass Spectrom 24: 3456-3460

Jarman WM, Hobson KA, Sydeman WJ, Bacon CE, McLaren EB (1996) Influence of trophic position and feeding location on contaminant levels in the Gulf of the Farallones food web revealed by stable isotope analysis. Environ Sci Technol 30:654-660

Karnovsky NJ, Hunt GL Jr (2002) Estimation of carbon flux to dovekies (Alle alle) in the North Water. Deep-Sea Res II 49:5117-5130

Karnovsky NJ, Hobson KA, Iverson SJ, Hunt GL Jr (2008) Seasonal changes in diets of seabirds in the North Water Polynya: a multiple-indicator approach. Mar Ecol Prog Ser 357:291-299

Karnovsky NJ, Hobson KA, Brown ZW, Hunt GL Jr (2009) Distribution and diet of ivory gulls (Pagophila eburnea) in the North Water Polynya. Arctic 62:65-74

Karnovsky NJ, Hobson KA, Iverson SJ (2012) From lavage to lipids: estimating diets of seabirds. Mar Ecol Prog Ser 451:263-284

Kojadinovic J, Ménard F, Bustamante P, Cosson RP, Le Corre M (2008a) Trophic ecology of marine birds and pelagic fishes from Réunion Island as determined by stable isotope analysis. Mar Ecol Prog Ser 361:239-251

Kojadinovic J, Richard P, Le Corre M, Cosson RP, Bustamante P (2008b) Effects of lipid extraction on $\delta^{13} \mathrm{C}$ and $\delta^{15} \mathrm{~N}$ values in seabird muscle, liver and feathers. Waterbirds 31:169-178

Meissner W (2002) Primary moult in the kittiwake (Rissa tridactyla) on Bear Island (Bjørnøya). Ornis Nor 25:49-51

Michener RH, Schell DM (1994) Stable isotopes as tracers in marine aquatic food webs. In: Lajtha $\mathrm{K}$, Michener RH (eds) Stable isotopes in ecology and environmental science. Blackwell Scientific Publications, Boston, MA, p 138-157

Minami H, Ogi H (1997) Determination of migratory dynamics of the sooty shearwater in the Pacific using stable carbon and nitrogen isotope analysis. Mar Ecol Prog Ser 158:249-256 
Mizutani H, Kabaya Y, Wada E (1991) Nitrogen and carbon isotope compositions relate linearly in cormorant tissues and its diet. Isotopenpraxis 27:166-168

Mizutani H, Fukuda M, Kabaya Y (1992) $\delta^{13} \mathrm{C}$ and $\delta^{15} \mathrm{~N}$ enrichment factors of feathers of 11 species of adult birds. Ecology 73:1391-1395

> Montevecchi WA (2007) Binary dietary responses of northern gannets Sula bassana indicate changing food web and oceanographic conditions. Mar Ecol Prog Ser 352: 213-220

Moody AT, Hobson KA (2007) Alcid winter diet in the northwest Atlantic determined by stable isotope analysis. Mar Ornithol 35:39-46

Moody AT, Hobson KA, Gaston AJ (2012) High-arctic seabird trophic variation revealed through long-term isotopic monitoring. J Ornithol (in press) doi:10.1007/ s10336-012-0836-0

Ofukany AFA, Hobson KA, Wassenaar LI (2012) Connecting breeding and wintering habitats of migratory piscivorous birds: implications for tracking contaminants (Hg) using multiple stable isotopes. Environ Sci Technol 46: 3263-3272

> Piatt JF, Harding AMA, Shultz MT, Speckman SG, van Pelt TI, Drew GS, Kettle AB (2007a) Seabirds as indicators of marine food supplies: Cairns revisited. Mar Ecol Prog Ser 352:221-234

> Piatt JF, Sydeman WJ, Weise F (2007b) Introduction: seabirds as indicators of marine ecosystems. Mar Ecol Prog Ser 352:199-204

Pyle P (2009) Age determination and molt strategies in North American alcids. Mar Ornithol 37:219-225

Quillfeldt P, Voigt CC, Masello JF (2010) Plasticity versus repeatability in seabird migratory behaviour. Behav Ecol Sociobiol 64:1157-1164

Rau GH, Chavez FP, Friederich GE (2001) Plankton ${ }^{13} \mathrm{C} /{ }^{12} \mathrm{C}$ variations in Monterey Bay, California: evidence of nondiffusive inorganic carbon uptake by phytoplankton in an upwelling environment. Deep-Sea Res I 48:79-94

Renaud WE, McLaren PL (1982) Ivory gull (Pagophila eburnea) distribution in late summer and autumn in eastern Lancaster Sound and Western Baffin Bay. Arctic 35: $141-148$

- Ryan TA (1959) Multiple comparisons in psychology research. Psychol Bull 56:26-47

Ryan TA (1960) Significance tests for multiple comparison of proportions, variances and other statistics. Psychol Bull 57:318-328

Schell DM, Barnett BA, Vinette KA (1998) Carbon and nirogen isotope ratios in zooplankton of the Bering, Chukchi and Beaufort Seas. Mar Ecol Prog Ser 162:11-23

Schoeninger MJ, DeNiro MJ (1984) Nitrogen and carbon isotopic composition of bone collagen form marine and terrestrial animals. Geochim Cosmochim Acta 48:625-639

Smith RJ, Hobson KA, Koopman HN, Lavigne DM (1996) Distinguishing between populations of fresh and saltwater harbour seals (Phoca vitulina) using stable-isotope ratios and fatty acid profiles. Can J Fish Aquat Sci 53: 272-279

Steele WK (2005) Stable isotope ratios of Antarctic petrel (Thalassoica antarctica) and snow petrel (Pagodroma nivea) bone collagen. Polar Biol 28:672-679

Stempniewicz L (2001) Alle alle. Little Auk. BWP Update 3: 175-201

Young HS, McCauley DJ, Dirzo R, Dunbar RB, Schaffer SA (2010) Niche partitioning among and within sympatric tropical seabirds revealed by stable isotope analysis. Mar Ecol Prog Ser 416:285-294

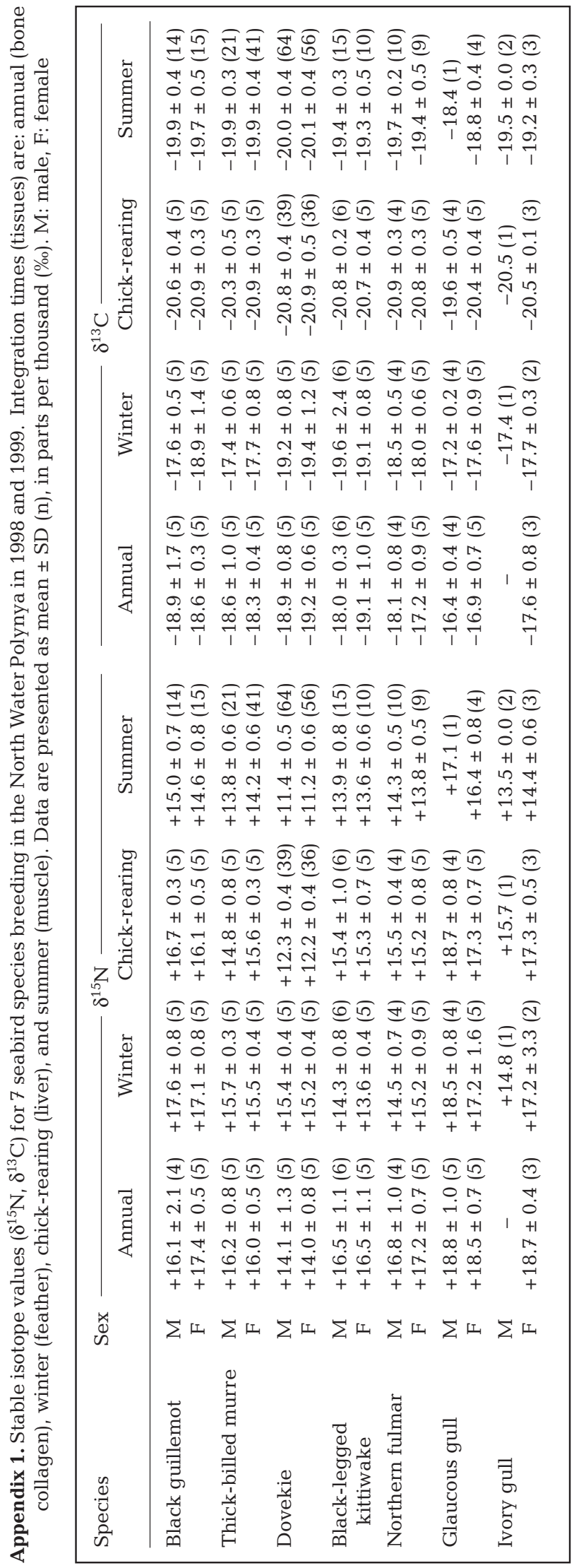

Submitted: December 2, 2011; Accepted: May 22, 2012 Proofs received from author(s): July 25, 2012 